\title{
Whole-Mount RNA In Situ Hybridization and Immunofluorescence of Xenopus Embryos and Tadpoles
}

\author{
Helen Rankin Willsey ${ }^{1}$ \\ Department of Psychiatry and Behavioral Sciences, Weill Institute for Neurosciences, University of California, \\ San Francisco, San Francisco, California 94143, USA
}

A major advantage of experimentation in Xenopus is the ability to query the localization of endogenous proteins and RNAs in situ in the entire animal during all of development. Here I describe three variations of staining to visualize mRNAs and proteins in developing Xenopus embryos and tadpoles. The first section outlines a traditional colorimetric staining for mRNAs that is suitable for all stages of development, and the second extends this protocol for fluorescence-based detection for higher spatial and quantitative resolution. The final section details detection of proteins by immunofluorescence, optimized for tadpole stages but widely applicable to others. Finally, optimization strategies are provided.

It is essential that you consult the appropriate Material Safety Data Sheets and your institution's Environmental Health and Safety Office for proper handling of equipment and hazardous materials used in this protocol.

RECIPES: Please see the end of this protocol for recipes indicated by $<R>$. Additional recipes can be found online at http://cshprotocols.cshlp.org/site/recipes.

Reagents required for the colorimetric RNA in situ hybridization procedure only (Steps 1-34)

Acetic anhydride (Sigma-Aldrich 320102)

Alkaline phosphatase buffer with tetramisole hydrochloride $<\mathrm{R}>$

Anti-digoxygenin-AP antibody (Sigma-Aldrich 11093274910)

Bleaching solution for in situ hybridization $<\mathrm{R}>$

BMB blocking solution $<\mathrm{R}>$

BM purple (Sigma-Aldrich 11442074001)

Bouin's fixative for in situ hybridization $<\mathrm{R}>$

Buffered ethanol $<\mathrm{R}>$

Digoxygenin-11-UTP-labeled RNA probes, in-vitro-transcribed (see Protocol: Synthesis and

Purification of Digoxigenin-Labeled RNA Probes for In Situ Hybridization [Sive et al. 2007a])

Both an experimental probe and a control probe (either sense-transcribed, or a probe with a known, very specific pattern) should be used.

Hybridization buffer for colorimetric in situ hybridization $<\mathrm{R}>$

\footnotetext{
${ }^{1}$ Correspondence: helen.willsey@ucsf.edu

From the Xenopus collection, edited by Hazel L. Sive.

(c) 2021 Cold Spring Harbor Laboratory Press

Cite this protocol as Cold Spring Harb Protoc; doi:10.1101/pdb.prot105635
} 
Maleic acid buffer $(\mathrm{MAB}, 10 \times)<\mathrm{R}>$

MEMFA $(1 \times)<$ R $>$

Methanol (Fisher A4544)

Molten agarose (1\%) (optional; see Step 33)

Paraformaldehyde (4\% in PTw)

Dilute $20 \%$ paraformaldehyde to $4 \%$ in PTw on staining day.

Paraformaldehyde $(20 \%)<\mathrm{R}>$

PBS with Tween 20 (PTw)

Add $0.1 \%$ Tween 20 to $1 \times$ PBS. Store at room temperature.

Phosphate-buffered saline (PBS) (10×; pH 7.4) <R>

Proteinase K $(10 \mathrm{mg} / \mathrm{mL}$; Fisher EO0491)

Proteinase $\mathrm{K}(10 \mu \mathrm{g} / \mathrm{mL}$ in PTw $)$

RNase A $(20 \mu \mathrm{g} / \mathrm{mL}$; Fisher EN0531)

RNase T1 $(10 \mu \mathrm{g} / \mathrm{mL}$; Fisher EN0542)

Sodium chloride-sodium citrate buffer $($ SSC; $20 \times)<\mathrm{R}>$

Triethanolamine (0.1 M, pH 7-8; Sigma-Aldrich T1502)

Xenopus tadpoles or embryos of any stage

Reagents required for the fluorescent RNA in situ hybridization by hybridization chain reaction

(HCR) procedure only (Steps 35-46)

Acetic anhydride (Sigma-Aldrich 320102)

Amplification buffer $<\mathrm{R}>$

HCR probes (custom-designed from Molecular Technologies)

HCR hairpins (standard-designed from Molecular Technologies)

Hybridization buffer for fluorescent in situ hybridization $(30 \%)<\mathrm{R}>$

MEMFA $(1 \times)<$ R $>$

Methanol (Fisher A4544)

Molten agarose (1\%) (optional; see Step 46)

Paraformaldehyde (4\% in PTw)

Dilute $20 \%$ paraformaldehyde to $4 \%$ in PTw on staining day.

Paraformaldehyde $(20 \%)<\mathrm{R}>$

PBS (10×; pH 7.4) <R>

PBS with Tween 20 (PTw)

Add $0.1 \%$ Tween 20 to $1 \times$ PBS. Store at room temperature.

Probe wash buffer $(30 \%)<\mathrm{R}>$

Proteinase K (10 mg/mL; Fisher EO0491)

Proteinase $\mathrm{K}(10 \mu \mathrm{g} / \mathrm{mL}$ in PTw $)$

$\operatorname{SSCT}(5 \mathrm{x})<\mathrm{R}>$

Triethanolamine (0.1 M, pH 7-8) (Sigma-Aldrich T1502)

Xenopus tadpoles or embryos of any stage

Reagents required for the immunofluorescence procedure only (Steps 47-58)

Bleaching solution for immunofluorescence $<\mathrm{R}>$

CAS-Block (10\% in PBT)

CAS-Block (Invitrogen 00-8120)

Gentamicin (optional; see Step 57)

Molten agarose (1\%) (optional; see Step 58)

Paraformaldehyde (4\% in PBS)

Dilute $20 \%$ paraformaldehyde to $4 \%$ in PBS on staining day.

Paraformaldehyde (20\%) 
H.R. Willsey

TABLE 1. Common antibodies compatible with this immunostaining procedure in stage 46 tadpoles along with relevant information

\begin{tabular}{|c|c|c|c|c|c|}
\hline Antigen & Labels & Host & Company & Product number & Dilution \\
\hline$\beta$-tubulin & Neurons, microtubules & Mouse & DSHB & E7 & $1: 100$ \\
\hline PCNA & Cells in S phase & Mouse & Life Technologies & 133900 & $1: 50$ \\
\hline $\mathrm{pHH} 3$ & Cells in $M$ phase & Rabbit & Millipore & $06-570$ & $1: 250$ \\
\hline$\alpha$-tubulin & Spindles, microtubules & Mouse & DSHB & $12 \mathrm{G} 10$ & $1: 100$ \\
\hline Ac- $\alpha$-tubulin & Cilia & Mouse & Sigma-Aldrich & T6793 & $1: 700$ \\
\hline Cleaved Caspase 3 & Cell death & Rabbit & BD Pharmingen & 559565 & $1: 250$ \\
\hline
\end{tabular}

PBS (10×; pH 7.4) <R>

PBS with Triton X-100 (PBT)

Add $0.1 \%$ Triton $\mathrm{X}-100$ to $1 \times$ PBS. Store at room temperature.

Primary antibodies

Potential primary antibodies are listed in Table 1.

Secondary antibodies compatible with the primary antibodies (fluorescently conjugated)

Xenopus tadpoles

\section{Equipment}

Aluminum foil

Equipment for basket format (high-throughput sample processing) only Baskets (Fig. 1A)
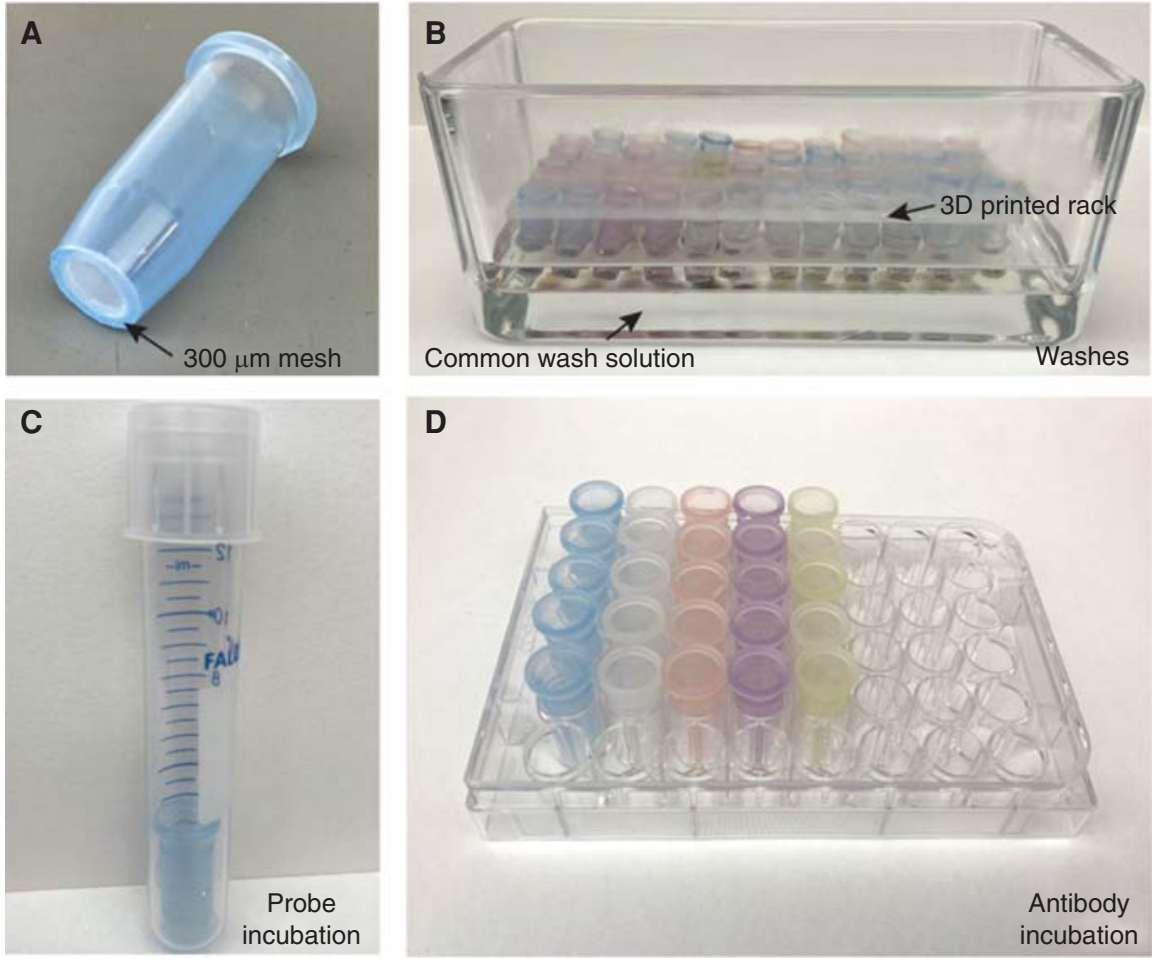

FIGURE 1. Basket format for higher-throughput staining. (A) Sample basket made from a 1.7-mL microcentrifuge tube (with cap and bottom cut off) with 300- $\mu \mathrm{m}$ mesh melted to the bottom. (B) Wash setup, with color-coded baskets arranged in a 3D-printed rack within a glass staining dish. Samples share a common wash buffer. (C) Probe incubation setup, in baskets within 15-mL round-bottom culture tubes with $500 \mu \mathrm{L}$ of probe solution. $(D)$ Antibody incubation setup within a 48-well culture plate with $500 \mu \mathrm{L}$ of antibody solution in each well. These incubation setups allow for each sample to experience a different probe or antibody, if desired, and minimize the total volume required. 

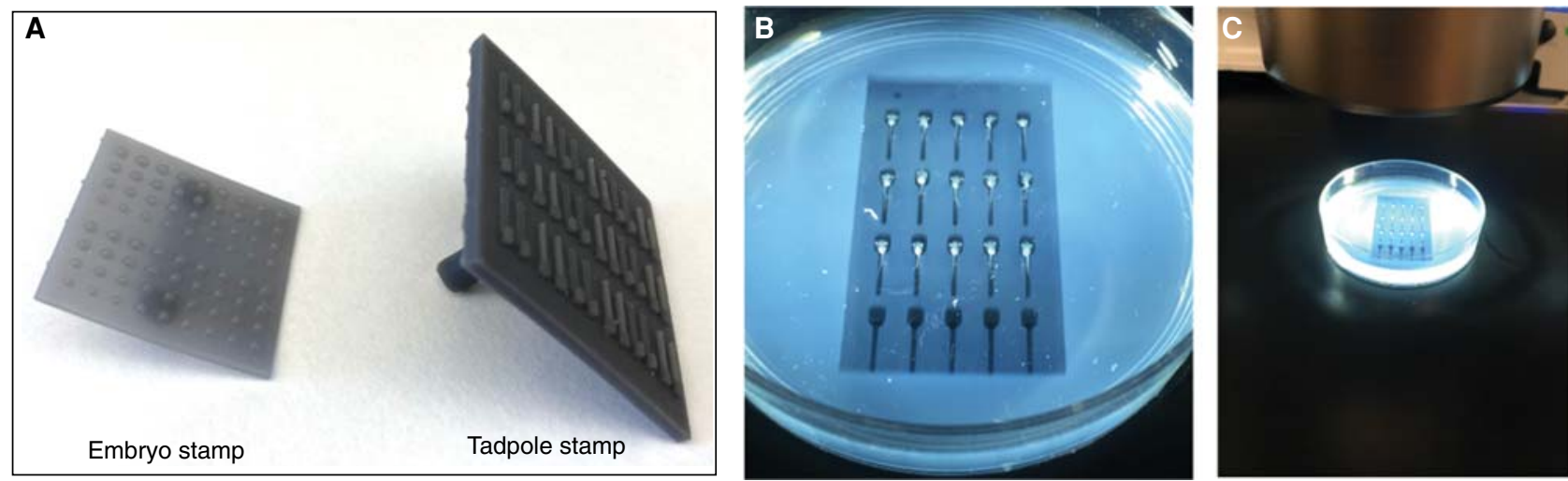

FIGURE 2. Imaging in agarose wells. (A) 3D-printed stamps for positioning embryos (left) or tadpoles (right). Agarose wells can be made by pressing these into molten agarose in a culture dish during cooling. (B) Tadpoles arranged into agarose wells. (C) Imaging animals using an upright stereoscope in agarose wells.

Construct the baskets from 1.7-mL tubes and 300- $\mu$ m nylon mesh (Spectra Mesh 146487); for dissected tissue, use finer mesh. For basket-making instructions, see Protocol: Baskets for In Situ Hybridization and Immunohistochemistry (Sive et al. 2007b).

Basket racks (Fig. 1B)

Prepare the basket racks using 3D printer files available at willseyfroggers.org/resources. Basket racks can also be made by cutting the bottoms off of $1.7-\mathrm{mL}$ tube racks.

Culture plates (48-well; Fisher 720086) (Fig. 1D)

Culture tubes (15-mL; Fisher 1496215E) (Fig. 1C)

Glass dish for washes (Fig. 1B)

Select a small dish (fits 24 baskets, holds $50 \mathrm{~mL}$ of wash buffer; Wheaton Inc. 900170), a medium dish (fits 30 baskets, holds $100 \mathrm{~mL}$ of wash buffer; Wheaton Inc. 900203), or a large dish (fits 60 baskets, holds $150 \mathrm{~mL}$ of wash buffer; Grainger 49WF37).

Lateral shaker at room temperature

Equipment for tube format (lower-throughput sample processing) only

Individual vials or tubes

Nutator at room temperature

Forceps

Glass slides and coverslips

Imaging stamps (Fig. 2A)

Prepare imaging stamps using 3D printer files available at willseyfroggers.org/resources.

Light box

Bright lights from a stereoscope can be substituted.

Syringes (1-mL)

These are used for dispensing vacuum grease onto glass slides for imaging.

Vacuum grease

Water bath $\left(37^{\circ} \mathrm{C}\right)$ with lateral agitation for in situ RNAs

Water bath $\left(60^{\circ} \mathrm{C}\right)$ with lateral agitation for in situ RNAs

Zeiss Axio Zoom.V16 microscope (or any appropriate microscope)

Three separate procedures are described here: colorimetric whole-mount RNA in situ hybridization (Steps 1-34), fluorescence whole-mount RNA in situ hybridization by HCR (Steps 35-46), and whole-mount immunofluorescence (Steps 47-58). See the Discussion section to determine the best procedure for your experiment. 
H.R. Willsey

These procedures have been optimized for higher-throughput staining (24 to 60 samples processed in parallel), with each sample in a basket within a large rack in a glass staining dish sharing a common buffer solution (Fig. 1; see Protocol: Baskets for In Situ Hybridization and Immunohistochemistry [Sive et al. 2007b]). This protocol is also effective, although lower-throughput, in individual vials or tubes with manual washes.

\section{Colorimetric Whole-Mount RNA In Situ Hybridization}

Perform all steps on a lateral shaker with light agitation ( $40 \mathrm{rpm})$.

\section{Fixation and Dehydration (2.5 h)}

1. Fix animals for $2 \mathrm{~h}$ in $1 \times$ MEMFA solution at room temperature.

This step and the following one can be done in basket format or in individual vials or tubes if planning on long-term storage before staining. If using the basket format, limit the number of animals in a basket to 20 and make sure they are well-covered by solutions. Consult one's IACUC protocol for whether anesthetization is required before fixation.

2. Wash several times in methanol at room temperature to dehydrate. Freeze at least overnight at $-20^{\circ} \mathrm{C}$.

Samples can be stored long term at $-20^{\circ} \mathrm{C}$.

\section{Rehydration and Permeabilization (55 min)}

3. Rehydrate stepwise into PTw at room temperature as follows:
i. 5 min in $100 \%$ methanol,
ii. 5 min in $75 \%$ methanol and $25 \% \mathrm{H}_{2} \mathrm{O}$,
iii. 5 min in $50 \%$ methanol and $50 \% \mathrm{H}_{2} \mathrm{O}$, and
iv. $5 \mathrm{~min}$ in $25 \%$ methanol and $75 \% \mathrm{PTw}$.

4. Wash four times for $5 \mathrm{~min}$ each time in PTw at room temperature.

5. Permeabilize in $10 \mu \mathrm{g} / \mathrm{mL}$ proteinase $\mathrm{K}$ in PTw for $5 \mathrm{~min}$ at room temperature.

This step should be carefully monitored and not prolonged. For staining of superficial structures like epidermal cilia, omit this step. For staining of deeper structures, this step can be extended with careful testing or combined with dissection for further permeabilization.

\section{Blocking and Hybridization (2.5 $h$ for Xenopus tropicalis, 7.5 for Xenopus laevis)}

6. Wash twice for $5 \mathrm{~min}$ each time in $0.1 \mathrm{~m}$ triethanolamine $(\mathrm{pH} 7-8)$ at room temperature.

7. Wash twice for $5 \mathrm{~min}$ each time in $0.1 \mathrm{~m}$ triethanolamine with acetic anhydride $(125 \mu \mathrm{L}$ of acetic anhydride per $50 \mathrm{~mL}$ of $0.1 \mathrm{M}$ triethanolamine) at room temperature.

8. Wash twice for 5 min each time in PTw at room temperature.

9. Refix for $20 \mathrm{~min}$ in $4 \%$ paraformaldehyde in PTw at room temperature.

10. Wash five times for 5 min each time in PTw at room temperature.

For fluorescence-based detection, proceed to Step 35.

11. Preheat probes at $1 \mu \mathrm{g} / \mathrm{mL}$ in hybridization buffer for colorimetric in situ hybridization for several hours at $60^{\circ} \mathrm{C}$ to help with penetration. In addition to your experimental probe, use a control probe (either sense-transcribed, or a probe with a known, very specific pattern).

12. Prehybridize samples in hybridization solution for $1 \mathrm{~h}$ (X. tropicalis) or $6 \mathrm{~h}($ X. laevis $)$ at $60^{\circ} \mathrm{C}$ with shaking.

Depending on the probe, this can be shortened to $1 \mathrm{~h}$ for X. laevis samples. Dissected tissues may also require less time than whole embryos.

13. Transfer samples into preheated probe solution overnight at $60^{\circ} \mathrm{C}$ with shaking. 
Save the prehybridization solution to reuse the next day in Step 15. For the basket format, remove baskets from the rack and place into 15-mL round-bottom culture tubes with $500 \mu \mathrm{L}$ of probe solution each (Fig. 1C). This allows each sample to have a different probe, if desired.

\section{Probe Detection (Time Varies)}

This is essentially an antibody staining against digoxygenin-11-UTP present in the RNA probe followed by enzymatic colorimetric detection. The procedure can be modified depending on the probe label and desired detection modality. Time to antibody incubation is $4.5 \mathrm{~h}$; antibody incubation can be done overnight at $4^{\circ} \mathrm{C}$ or $4 \mathrm{~h}$ at room temperature; $M A B$ washes can be done overnight at $4^{\circ} \mathrm{C}$ or for $5 \mathrm{~h}$ at room temperature; AP buffer washes take 15 min; and developing the stain in BM Purple varies from $1 \mathrm{~h}$ to days depending on the probe and sample.

14. Remove the probe solution and save at $-20^{\circ} \mathrm{C}$ for reuse.

15. Wash samples in hybridization buffer, reused from Step 12 , for 5 min at $60^{\circ} \mathrm{C}$.

16. Wash twice for $3 \mathrm{~min}$ each time in $2 \times \mathrm{SSC}$ at $60^{\circ} \mathrm{C}$.

17. Wash three times for 20 min each time in $2 \times \operatorname{SSC}$ at $60^{\circ} \mathrm{C}$.

18. Incubate for $30 \mathrm{~min}$ at $37^{\circ} \mathrm{C}$ in $2 \times \mathrm{SSC}$ containing $20 \mu \mathrm{g} / \mathrm{mL}$ RNase A and $10 \mu \mathrm{g} / \mathrm{mL}$ RNase $\mathrm{T}_{1}$.

19. Wash once for $10 \mathrm{~min}$ in $2 \times \mathrm{SSC}$ at room temperature.

20. Wash twice for $30 \mathrm{~min}$ each time in $0.2 \times \mathrm{SSC}$ at $60^{\circ} \mathrm{C}$.

21. Wash twice for $10 \mathrm{~min}$ each time in $1 \times \mathrm{MAB}$ at room temperature.

22. Incubate in $2 \% \mathrm{BMB}$ blocking solution for at least $1 \mathrm{~h}$ at room temperature.

23. Incubate in antibody solution (dilute anti-digoxigenin-AP antibody 1:3000 in 2\% BMB blocking solution) overnight at $4^{\circ} \mathrm{C}$ or for $4 \mathrm{~h}$ at room temperature.

For basket format in a dish, this is $16.6 \mu \mathrm{L}$ of antibody per $50 \mathrm{~mL}$ of blocking solution. Alternatively, baskets can be transferred into a 48-well plate to use less total antibody, in which case each well has $500 \mu \mathrm{L}$ of diluted antibody.

24. Wash five times for $1 \mathrm{~h}$ each time in $1 \times \mathrm{MAB}$ at room temperature (or wash overnight at $4^{\circ} \mathrm{C}$ with multiple quick washes before and after overnight incubation).

25. Wash twice for 5 min each time in alkaline phosphatase buffer with tetramisole hydrochloride at room temperature.

26. Incubate in BM Purple reagent in wells of a 48 -well plate at room temperature (Fig. 1D), protected from light with aluminum foil, and monitor until chromogenic reaction produces a stain of the desired intensity.

Incubation time in BM Purple varies widely depending on the probe and can only be determined empirically or by comparison to published literature for a given probe.

Depending on the stage and tissue interrogated, endogenous pigment may make the visualization of BM Purple precipitate difficult. Bleaching (see Steps 28-34) may make the signal easier to see. Consider this as the chromogenic reaction proceeds. If pigment precludes sensitive monitoring, consider using albino embryos at the start.

27. Stop the chromogenic reaction with a wash in $1 \times \mathrm{MAB}$ at room temperature.

\section{Postfixation and Bleaching (6 h)}

28. Fix for at least $2 \mathrm{~h}$ in Bouin's fixative at room temperature.

29. Wash at room temperature in buffered ethanol solution 10 times for 10 min each time or until the embryos are no longer yellow.

30. Rehydrate stepwise into $1 \times$ SSC at room temperature as follows:

i. $5 \mathrm{~min}$ in $75 \%$ buffered ethanol and $25 \% 1 \times$ SSC,

ii. $5 \mathrm{~min}$ in $50 \%$ buffered ethanol and $50 \% 1 \times$ SSC,

iii. $5 \mathrm{~min}$ in $25 \%$ buffered ethanol and $75 \% 1 \times$ SSC, and 
H.R. Willsey

iv. twice for 5 min each time in $100 \% 1 \times$ SSC.

31. Bleach in bleaching solution for in situ hybridization for $1-2 \mathrm{~h}$ at room temperature under a light box or until embryos are white.

32. Wash three times for 5 min each time in $1 \times$ SSC at room temperature.

At this point, the samples are ready for imaging. The samples can be stored for years at $-20^{\circ} \mathrm{C}$ in methanol or for months at $4^{\circ} \mathrm{C}$ in $1 \times$ SSC.

33. Mount the samples for imaging as follows:

- For macroscale imaging, mount samples in agarose wells made using 3D printed stamps pressed in $1 \%$ molten agarose during cooling (Fig. 2).

3D printer files for stamps are available at willseyfroggers.org/resources.

- Alternatively, mount on glass slides in $1 \times$ SSC within a vacuum grease well and affix a coverslip.

34. Image using brightfield microscopy.

See Troubleshooting.

Fluorescence Whole-Mount RNA In Situ Hybridization by Hybridization Chain Reaction (HCR)

This method is identical to the previous one until prehybridization. Perform all steps on a lateral shaker with light agitation ( $40 \mathrm{rpm})$.

Fixation, Dehydration, Rehydration, Permeabilization, and Blocking

35. Carry out Steps 1-10, and then proceed to Step 36.

\section{Hybridization (35 min until Overnight Incubation; 1.5 h until Amplification)}

36. Prehybridize samples in $30 \%$ probe hybridization buffer for fluorescent in situ hybridization for $30 \mathrm{~min}$ at $37^{\circ} \mathrm{C}$.

37. Prepare probe solution by adding 2 pmol of each probe as provided by Molecular Technologies ( $1 \mu \mathrm{L}$ of $2 \mu \mathrm{M}$ stock per probe mixture) to $500 \mu \mathrm{L}$ of $30 \%$ probe hybridization buffer that has been prewarmed to $37^{\circ} \mathrm{C}$. In addition to your experimental probe, ideally use a control probe (either sense-transcribed, or a probe with a known, very specific pattern).

Probe volume can be reduced to the minimum required to cover samples.

38. Replace the $30 \%$ probe hybridization buffer with probe solution and incubate overnight (12-16 h) at $37^{\circ} \mathrm{C}$ with shaking.

For the basket format, remove baskets from the rack and place into 15-mL round bottom culture tubes with 300-500 $\mu \mathrm{L}$ of probe solution each (Fig. 1C).

39. Wash four times for 15 min each time in $30 \%$ probe wash buffer at $37^{\circ} \mathrm{C}$ with shaking. Save probe solutions. They can be stored at $-20^{\circ} \mathrm{C}$ and reused multiple times.

Heat wash solutions to $37^{\circ} \mathrm{C}$ before use.

40. Wash samples three times for 5 min each time in $5 \times$ SSCT at room temperature with shaking.

Amplification (35 min until Overnight Incubation; 1.5 h until Mounting)

41. Incubate samples in amplification buffer for $30 \mathrm{~min}$ at room temperature.

42. Prepare $30 \mathrm{pmol}$ hairpin solutions ( $10 \mu \mathrm{L}$ of each desired $3 \mu \mathrm{M}$ hairpin) in amplification buffer as follows:

i. heat hairpins for $90 \mathrm{sec}$ at $95^{\circ} \mathrm{C}$, 
Downloaded from http://cshprotocols.cshlp.org/ on April 26, 2023 - Published by

ii. cool for $30 \mathrm{~min}$ in a dark drawer to room temperature, and

iii. add all hairpin solutions to amplification buffer (for a total volume of $500 \mu \mathrm{L}$ ) at room temperature.

43. Transfer samples into the hairpin solution and incubate overnight (12-16 h) in the dark at room temperature.

Hairpin solutions can be stored at $-20^{\circ} \mathrm{C}$ and reused multiple times. For the basket format, remove baskets from the rack and place into $15-\mathrm{mL}$ round bottom culture tubes with 300-500 $\mu \mathrm{L}$ of hairpin solution each (Fig. 1C).

44. Wash in $5 \times$ SSCT at room temperature as follows:

i. twice for 5 min each time,

ii. twice for $30 \mathrm{~min}$ each time, and

iii. once for $5 \mathrm{~min}$.

45. Wash three times for 5 min each time in $1 \times$ SSC at room temperature.

At this point, the samples are ready for imaging. The samples can be stored for weeks in the dark at $4^{\circ} \mathrm{C}$ in $1 \times$ SSC.

46. Mount and image as follows:

- For macroscale imaging, place in $1 \times$ SSC in agarose wells made using 3D printed stamps pressed in $1 \%$ molten agarose during cooling (Fig. 2). Image on an upright stereomicroscope with fluorescence.

3D printer files for stamps are available at willseyfroggers.org/resources.

- For higher-magnification imaging, mount in $1 \times$ SSC in a vacuum grease well on a glass slide, affix coverslip, and image.

See Troubleshooting.

Whole-Mount Immunofluorescence

Perform all incubations (excluding antibody incubations) on a lateral shaker (basket format) or on a nutator (tube format).

Fixation (1 h)

47. Fix animals in $4 \%$ paraformaldehyde in PBS for $40 \mathrm{~min}$ at room temperature.

Consult one's IACUC protocol for whether anesthetization is required before fixation.

48. Wash in PBS three times for 5 min each time at room temperature.

Bleaching and Permeabilization (2 h, 5 min)

49. Bleach samples in bleaching solution for immunofluorescence for $1 \mathrm{~h}$ at room temperature under a light box.

This step is incompatible with phalloidin staining and will quench any fluorescent proteins (e.g., GFP); therefore, it should be omitted in those cases.

Bubbles are created in this step. If using tubes, transfer samples to a glass dish or open the tube tops to allow for gas release.

This step will remove pigmentation and provide some permeabilization. It should not be prolonged as it can begin to disintegrate the sample if performed for too long.

50. Permeabilize in PBT by washing three times for 20 min each time at room temperature. For stages younger than 44, additional permeabilization may be required, such as dehydration.

Blocking and Incubation with Primary Antibody (1 h until Overnight Incubation)

51. Block in 10\% CAS-Block in PBT for at least $1 \mathrm{~h}$ at room temperature. 
H.R. Willsey

52. Incubate in primary antibody diluted in $100 \%$ CAS-Block overnight at $4^{\circ} \mathrm{C}$.

If using baskets, move the baskets into 48-well plates with $300 \mu \mathrm{L}$ of antibody per well (Fig. 1D). If using tubes, use a minimum volume to cover animals completely.

A reasonable starting concentration for a new antibody is 1:100, but the concentration should be optimized empirically. For unconcentrated sera (e.g., from DSHB), start with a 1:5 dilution.

Washes and Incubation with Secondary Antibody (3 h, $10 \mathrm{~min}$ )

53. Wash in PBT three times for 10 min each time at room temperature.

54. Block in 10\% CAS-Block in PBT for $30 \mathrm{~min}$ at room temperature.

55. Incubate in secondary antibody diluted in $100 \%$ CAS-Block for $2 \mathrm{~h}$ in the dark at room temperature.

If using baskets, move the baskets into 48-well plates with $300 \mu \mathrm{L}$ of antibody per well (Fig. 1D). If using tubes, use a minimum volume to cover embryos completely.

If using fluorescence-conjugated secondary antibodies, cover tubes or baskets with aluminum foil to protect samples from the light for the remainder of the staining.

A typical commercial antibody dilution for this step is 1:250. Additional fluorescent dyes can be added during this step (e.g., DAPI).

Washes and Mounting (1.5 h until Mounting)

56. Wash three times for 10 min each time in PBT at room temperature.

57. Wash three times for 20 min each time in PBS at room temperature.

At this point, the samples are ready for imaging. The samples can be stored for a few weeks at $4^{\circ} \mathrm{C}$ in $1 \times P B S$. If in solution, rather than mounted, add gentamicin $(50 \mu \mathrm{g} / \mathrm{mL})$ to the $1 \times$ PBS to extend storage time. An additional, final fixation for 40 min at room temperature in $4 \%$ paraformaldehyde in PBS (post-fixation) can also extend storage time if necessary.

58. Mount and image as follows:

- For macroscale imaging, place in $1 \times$ PBS in agarose wells made using 3D printed stamps pressed in molten agarose during cooling (Fig. 2). Image on an upright stereomicroscope.

- For higher-magnification imaging, mount in $1 \times$ PBS in a vacuum grease well on a glass slide, affix coverslip, and image.

See Troubleshooting.

Problem (Step 34, 46, or 58): Superficial staining is observed, but there is an absence of deeper tissue staining.

Solution: Increase permeabilization by a longer or more concentrated proteinase K treatment (for RNA hybridization), a longer or more concentrated detergent treatment (for RNA or protein staining), or by physically dissecting the tissue to expose the target region. Adding a dehydration step to the immunofluorescence protocol may increase permeabilization.

Problem (Step 34, 46, or 58): Tissue disintegrates during the procedure.

Solution: Increase fixation time and/or decrease proteinase K or detergent washes.

Problem (Step 34, 46, or 58): Excessive background staining is observed.

Solution: Increase stringency steps (longer $0.2 \times$ SSC washes and increased temperature for RNA hybridization; increased blocking time and permeabilization for immunostaining). 
Problem (Step 58): Weak antibody staining is observed.

Solution: Empirically test alternative fixatives (e.g., try glutaraldehyde), antibody concentration, bleaching time, and/or detergent concentration.

Problem (Step 58): No signal is seen.

Solution: Refer to other excellent protocols for additional steps (dehydration, etc.), alternative fixatives, and additional positive control antibodies (e.g., Protocol: Whole-Mount Fluorescence Immunocytochemistry on Xenopus Embryos [Lee et al. 2008] and Brooks and Wallingford [2015]).

\section{DISCUSSION}

Three separate procedures are described in this protocol. The first involves whole-mount RNA in situ hybridization with colorimetric detection by BM Purple staining (Steps 1-34; Fig. 3A). This is a cost-effective strategy for assaying mRNA expression in embryos and tadpoles of all stages using invitro-transcribed digoxygenin-11-UTP-labeled RNA probes (see Protocol: Synthesis and Purification of Digoxigenin-Labeled RNA Probes for In Situ Hybridization [Sive et al. 2007a]). The second, whole-mount RNA in situ hybridization with fluorescent detection by HCR (Steps 3546; Fig. 3B,C; Choi et al. 2018), is more expensive for assaying mRNA expression because it requires commercial RNA probes designed for Xenopus sequences (https://www.moleculartechnologies.org), but these probes can be reused. Fluorescence-based detection provides a great increase in spatial and quantitative resolution over colorimetric detection as well as the ability to label up to five RNAs in different wavelengths. Because of the nature of detection, there is also not the subjectivity of when to terminate the development of signal, which can be an advantage over colorimetric detection in some respects.

The third procedure involves whole-mount immunostaining with fluorescent detection (Steps 4758; Fig. 3D). Although it is optimized for tadpole stages, it also works well for many epitopes in earlier stages, including before gastrulation. See Table 1 for a list of primary antibodies compatible with this procedure, particularly for stage 46 tadpoles. Because this is one of the simpler procedures available, it is a good one to try first.

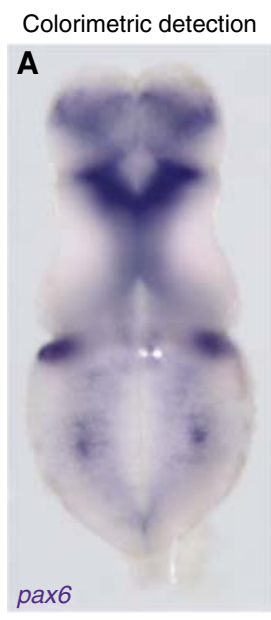

Hyrbidization chain reaction ( $\mathrm{HCR})$ maximum intensity projection

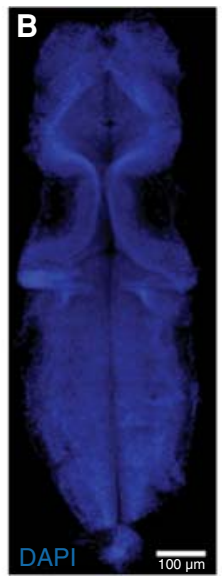

Hyrbidization chain reaction ( $\mathrm{HCR})$ Single plane

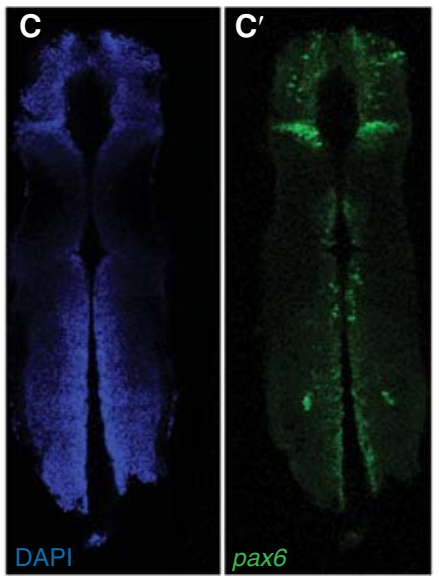

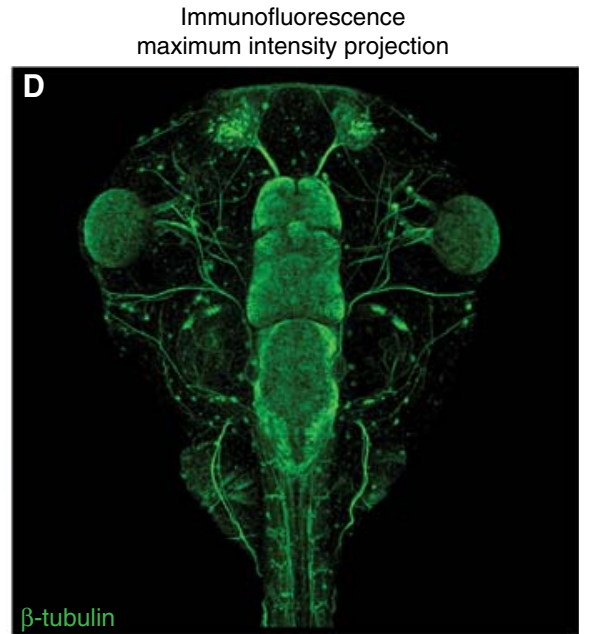

FIGURE 3. Sample RNA in situ hybridization and immunostaining micrographs. (A) Colorimetric staining for pax6 RNA (purple) in a stage 46 Xenopus tropicalis dissected brain imaged by widefield microscopy. $(B, C)$ Fluorescence staining for pax6 RNA by HCR (green; $B^{\prime}, C^{\prime}$ ) costained with DAPI to label nuclei (blue; $B, C$ ) in a stage $46 X$. tropicalis dissected brain imaged by confocal microscopy. $\left(B-B^{\prime}\right)$ Maximum intensity projection of confocal sections. $\left(C-C^{\prime}\right)$ Single imaging plane. Note the increased resolution potential with the fluorescence-based method. $(D)$ Immunostaining for $\beta$-tubulin in the stage $46 X$. tropicalis head region imaged by confocal microscopy. 
H.R. Willsey

The procedures in this protocol should be modified according to the developmental stage and tissue type of interest. For example, dehydration is often helpful in earlier, more yolky stages, whereas it can interfere with staining in later tadpole stages. Some tissues and stages require physical permeabilization (e.g., removal of skin in later tadpole stages to better permeabilize the brain), whereas superficial tissues may need less permeabilization (e.g., omit the proteinase $\mathrm{K}$ step for epidermal cilia staining). Further, some antibodies produce better results with a particular fixative, permeabilization condition, etc., and require empirical testing to optimize (see Troubleshooting).

On a final note, the colorimetric RNA in situ procedure was derived from a widely used contribution from Joanna Yeh and Mustafa Khokha according to Sive et al. (2000) and originally described in Harland (1991). The fluorescent RNA in situ procedure was derived from Choi et al. (2018), and the imaging stamps were derived from Truchado-Garcia et al. (2018).

\section{ACKNOWLEDGMENTS}

I thank Cameron Exner for careful editing; Richard Harland, Edivinia Pangilinan, Mustafa Khokha, Maura Lane, Emily Mis, Karen Liu, Peter Walentek, Yuxiao Xu, and Cameron Exner for expert instruction and modifications of these procedures; Yuxiao Xu for the pax6 colorimetric image; and Albert Kim, Marta Truchado-Garcia, and Richard Harland for help with 3D-printing racks and stamps.

\section{RECIPES}

Alkaline Phosphatase Buffer with Tetramisole Hydrochloride

\begin{tabular}{lcc} 
Reagent & Volume (for 1 L) & Final concentration \\
\hline Tris (1 M, pH 9.5) & $100 \mathrm{~mL}$ & $100 \mathrm{~mm}$ \\
$\mathrm{MgCl}_{2}(1 \mathrm{M})$ & $50 \mathrm{~mL}$ & $50 \mathrm{mM}$ \\
$\mathrm{NaCl}(4 \mathrm{M})$ & $25 \mathrm{~mL}$ & $100 \mathrm{~mm}$ \\
Tween 20 & $1 \mathrm{~mL}$ & $0.1 \%$ \\
Tetramisole hydrochloride $(1 \mathrm{M} ;$ & $2 \mathrm{~mL}$ & $2 \mathrm{~mm}$
\end{tabular}

Sigma-Aldrich L9756)

Adjust to $1 \mathrm{~L}$ with $\mathrm{H}_{2} \mathrm{O}$ and store at $-20^{\circ} \mathrm{C}$ in $50-\mathrm{mL}$ aliquots.

\section{Amplification Buffer}

\begin{tabular}{lcc} 
Reagent & Volume $($ for $40 \mathrm{~mL})$ & Final concentration \\
\hline $\begin{array}{l}\text { Sodium chloride-sodium citrate } \\
\text { buffer }(\text { SSC; } 20 \times)<\mathrm{R}>\end{array}$ & $10 \mathrm{~mL}$ \\
Tween $20(10 \%)$ & $400 \mu \mathrm{L}$ & $5 \times$ \\
Dextran sulfate $(50 \% \mathrm{w} / \mathrm{v}$ in & $8 \mathrm{~mL}$ & $1 \% \%$ \\
$\left.\mathrm{H}_{2} \mathrm{O}\right)$ & & \\
Adjust to $40 \mathrm{~mL}$ with $\mathrm{H}_{2} \mathrm{O}$. Store at room temperature. &
\end{tabular}


Bleaching Solution for Immunofluorescence

Reagent Volume (for $100 \mathrm{~mL}$ ) Final concentration

$\begin{array}{lrr}\text { PBS }(10 \times ; \mathrm{pH} 7.4)<\mathrm{R}> & 10 \mathrm{~mL} & 1 \times \\ \text { Formamide } & 5 \mathrm{~mL} & 5 \% \\ \text { Peroxide }(30 \%) & 4 \mathrm{~mL} & 1.2 \% \\ \mathrm{H}_{2} \mathrm{O} & 81 \mathrm{~mL} & \end{array}$

Add the formamide and peroxide to the larger volume of PBS, in that order only; formamide and peroxide can become explosive if mixed directly together. This solution must be made fresh. Do not store.

\section{Bleaching Solution for In Situ Hybridization}

\begin{tabular}{lcc} 
Reagent & Volume (for $100 \mathrm{~mL})$ & Final concentration \\
\hline $\begin{array}{l}\text { Sodium chloride-sodium citrate } \\
\quad \text { buffer }(S S C ; 20 \times)<\mathrm{R}>\end{array}$ & $2.5 \mathrm{~mL}$ & $0.5 \times$ \\
Formamide & $5 \mathrm{~mL}$ & $5 \%$ \\
Peroxide $(30 \%)$ & $4 \mathrm{~mL}$ & $1.2 \%$ \\
$\mathrm{H}_{2} \mathrm{O}$ & $88.5 \mathrm{~mL}$ &
\end{tabular}

Add the formamide and peroxide to the larger volume of SSC, in that order only; formamide and peroxide can become explosive if mixed directly together. This solution must be made fresh. Do not store.

\section{BMB Blocking Solution}

\begin{tabular}{lcc} 
Reagent & Quantity (for $500 \mathrm{~mL})$ & Final concentration \\
\hline $\begin{array}{l}\text { BMB Blocking Agent } \\
\quad \text { Sigma-Aldrich }\end{array}$ & $50 \mathrm{~g}$ & $10 \%$ \\
$\begin{array}{l}11096176001) \\
\text { Maleic acid buffer (MAB; } \\
10 \times)<\mathrm{R}>\end{array}$ & $50 \mathrm{~mL}$ & $1 \times$
\end{tabular}

Adjust to $500 \mathrm{~mL}$ with $\mathrm{H}_{2} \mathrm{O}$. Mix with heat until dissolved. Store this $10 \%$ solution at $-20^{\circ} \mathrm{C}$ in $50-\mathrm{mL}$ aliquots. Dilute to $2 \%$ with $1 \times \mathrm{MAB}$ on staining day.

Bouin's Fixative for In Situ Hybridization

Reagent

Picric acid (saturated)

Formaldehyde (37\%)

Acetic acid (glacial)
Volume (for $100 \mathrm{~mL}$ )

$\begin{array}{rr}70 \mathrm{~mL} & 70 \% \\ 25 \mathrm{~mL} & 9.25 \% \\ 5 \mathrm{~mL} & 5 \%\end{array}$

Store in a glass container in a corrosive cabinet at room temperature.

Buffered Ethanol

\begin{tabular}{lcc} 
Reagent & Volume (for 4 L) & Final concentration \\
\hline Ethanol $(95 \%)$ & $3.9 \mathrm{~L}$ & $92.625 \%$ \\
Tris $(1 \mathrm{M}, \mathrm{pH} 8)$ & $100 \mathrm{~mL}$ & $25 \mathrm{~mm}$ \\
EDTA $(0.5 \mathrm{M})$ & $10 \mathrm{~mL}$ & $1.25 \mathrm{~mm}$
\end{tabular}

Adjust to $4 \mathrm{~L}$ with $\mathrm{H}_{2} \mathrm{O}$. Store in a flammables cabinet at room temperature. 
H.R. Willsey

Denhardt's Solution (100x)

\begin{tabular}{lcc} 
Reagent & Quantity (for $50 \mathrm{~mL})$ & $\begin{array}{c}\text { Final concentration } \\
(100 \times)\end{array}$ \\
\hline Bovine serum albumin (Fraction V) & $1 \mathrm{~g}$ & $2 \%(\mathrm{w} / \mathrm{v})$ \\
Ficoll 400 & $1 \mathrm{~g}$ & $2 \%(\mathrm{w} / \mathrm{v})$ \\
Polyvinylpyrrolidone (PVP) & $1 \mathrm{~g}$ & $2 \%(\mathrm{w} / \mathrm{v})$ \\
$\mathrm{H}_{2} \mathrm{O}$ & to $50 \mathrm{~mL}$ &
\end{tabular}

Dissolve the components in the $\mathrm{H}_{2} \mathrm{O}$. Filter to sterilize and remove particulate matter. Divide into aliquots, and store at $-20^{\circ} \mathrm{C}$.

Hybridization Buffer for Colorimetric In Situ Hybridization

Reagent Quantity (for $3 \mathrm{~L}$ ) Final concentration

Formamide

Sodium chloride-sodium citrate buffer (SSC; 20×) $<\mathrm{R}>$

Torula RNA Type IX (Sigma-Aldrich R3629)

Heparin (Sigma-Aldrich H3393)

Denhardt's solution $(100 \times)<\mathrm{R}>$

Tween 20

CHAPS (Sigma-Aldrich C3023)

EDTA

Adjust to $3 \mathrm{~L}$ with $\mathrm{H}_{2} \mathrm{O}$, check that $\mathrm{pH}$ is $\sim 7.5$, and store at $-20^{\circ} \mathrm{C}$.

Hybridization Buffer for Fluorescent In Situ Hybridization (30\%)

Reagent

Quantity (for $40 \mathrm{~mL}$ )

Final concentration

Formamide

Sodium chloride-sodium

$12 \mathrm{~mL}$

$10 \mathrm{~mL}$

$30 \%$

citrate buffer (SSC; 20X) $<\mathrm{R}>$

Citric acid ( $1 \mathrm{M}, \mathrm{pH} 6.0)$

Tween 20 (10\%)

Heparin $(10 \mathrm{mg} / \mathrm{mL}$; Sigma-Aldrich H3393)

Denhardt's solution $(100 \times)<\mathrm{R}>$

Dextran sulfate $\left(50 \%\right.$, w/v, in $\left.\mathrm{H}_{2} \mathrm{O}\right)$

Adjust to $40 \mathrm{~mL}$ with $\mathrm{H}_{2} \mathrm{O}$. Store at $-20^{\circ} \mathrm{C}$.

Maleic Acid Buffer (MAB, 10×)

Reagent

Quantity (for 4 L)

Final concentration

Maleic acid (Sigma-Aldrich M0375)

$\mathrm{NaCl}$

$464.4 \mathrm{~g}$

$1 \mathrm{M}$

$350.6 \mathrm{~g}$

$1.5 \mathrm{~mm}$

Adjust the $\mathrm{pH}$ to 7.2 with $\sim 280 \mathrm{~g}$ of $\mathrm{NaOH}$, and then bring the final volume to $4 \mathrm{~L}$ with $\mathrm{H}_{2} \mathrm{O}$. Store at room temperature.

Adjusting the $\mathrm{pH}$ here is an exothermic acid-base reaction and often takes a long time. Mix in a $4^{\circ} \mathrm{C}$ room, adding $70 \mathrm{~g}$ of $\mathrm{NaOH}$ at a time. 
$\operatorname{MEMFA}(1 \times)$

Reagent

MEM salts $(10 \times$ stock $)<\mathrm{R}>$

Formaldehyde (37\%)

$\mathrm{H}_{2} \mathrm{O}$

Store at room temperature.

MEM Salts $(10 \times$ Stock)

Reagent Quantity (for 1 L)

Final concentration

MOPS

EGTA

$209.3 \mathrm{~g}$

$7.6 \mathrm{~g}$

$1.2 \mathrm{~g}$

$\mathrm{MgSO}_{4}$

Adjust the $\mathrm{pH}$ to 7.4 with $\mathrm{NaOH}$, and bring the final volume to $1 \mathrm{~L}$ with $\mathrm{H}_{2} \mathrm{O}$. Autoclave for 20 min. (10× MEM salts turn yellow after autoclaving.) Store at room temperature.

Paraformaldehyde (20\%)

Reagent Quantity (for $500 \mathrm{~mL}$ )

Final concentration

Paraformaldehyde $100 \mathrm{~g}$

$\mathrm{H}_{2} \mathrm{O}$

$500 \mathrm{~mL}$

Prepare 20\% paraformaldehyde by boiling distilled water and then adding $20 \mathrm{~g}$ of solid paraformaldehyde per $100 \mathrm{~mL}$ of $\mathrm{H}_{2} \mathrm{O}$ with stirring. Add $\mathrm{NaOH}$ pellets until the paraformaldehyde is dissolved. Aliquot in $50-\mathrm{mL}$ tubes and store at $-20^{\circ} \mathrm{C}$.

To make a $4 \%$ paraformaldehyde fixative solution, thaw $20 \%$ aliquots (may need to heat in a water bath for solute to go back into solution) and dilute in the appropriate buffer on staining day.

PBS (10x; $p H 7.4)$

$320 \mathrm{~g} \mathrm{NaCl}$

$8 \mathrm{~g} \mathrm{KCl}$

$57.6 \mathrm{~g} \mathrm{Na}_{2} \mathrm{HPO}_{4}$

$9.6 \mathrm{~g} \mathrm{KH}_{2} \mathrm{PO}_{4}$

Dissolve in $3 \mathrm{~L}$ of distilled $\mathrm{H}_{2} \mathrm{O}$. Adjust the $\mathrm{pH}$ to 7.4. Bring to $4 \mathrm{~L}$ with distilled $\mathrm{H}_{2} \mathrm{O}$. Autoclave. Store at room temperature indefinitely.

Probe Wash Buffer (30\%)

Reagent

Volume (for $40 \mathrm{~mL}$ )

Final concentration

Formamide

$12 \mathrm{~mL}$

$30 \%$

Sodium chloride-sodium

$10 \mathrm{~mL}$

$5 \times$

citrate buffer (SSC; 20×) $<\mathrm{R}>$

Citric acid (1 M, pH 6.0)

Tween $20(10 \%)$

Heparin $(10 \mathrm{mg} / \mathrm{mL})$

$360 \mu \mathrm{L}$

$9 \mathrm{~mm}$

$400 \mu \mathrm{L}$

$0.1 \%$

$200 \mu \mathrm{L}$

$50 \mu \mathrm{g} / \mathrm{mL}$

Adjust to $40 \mathrm{~mL}$ with $\mathrm{H}_{2} \mathrm{O}$. Store at $-20^{\circ} \mathrm{C}$. 
H.R. Willsey

Sodium Chloride-Sodium Citrate Buffer (SSC; 20x)

\begin{tabular}{lcc} 
Reagent & Quantity (for $4 \mathrm{~L}$ ) & Final concentration \\
\hline $\mathrm{NaCl}$ & $701.1 \mathrm{~g}$ & $3 \mathrm{M}$ \\
$\mathrm{Na}_{3}$ citrate $\cdot 2 \mathrm{H}_{2} \mathrm{O}$ & $352.8 \mathrm{~g}$ & $0.3 \mathrm{M}$
\end{tabular}

Adjust the $\mathrm{pH}$ to 7.0 with $\mathrm{HCl}$ or $10 \mathrm{~N} \mathrm{NaOH}$, and then bring the final volume to 4 L with $\mathrm{H}_{2} \mathrm{O}$. Store at room temperature.

$\operatorname{SSCT}(5 \times)$

\begin{tabular}{lcc} 
Reagent & Volume (for $40 \mathrm{~mL})$ & Final concentration \\
\hline $\begin{array}{l}\text { Sodium chloride-sodium citrate } \\
\text { buffer }(\text { SSC; } 20 \times)<\mathrm{R}>\end{array}$ & $10 \mathrm{~mL}$ & $5 \times$ \\
$\begin{array}{l}\text { Tween } 20(10 \%) \\
\text { Twe }\end{array}$ & $400 \mu \mathrm{L}$ & $0.1 \%$
\end{tabular}

Adjust to $40 \mathrm{~mL}$ with $\mathrm{H}_{2} \mathrm{O}$. Store at room temperature.

\section{REFERENCES}

Brooks ER, Wallingford JB. 2015. In vivo investigation of cilia structure and function using Xenopus. Methods Cell Biol 127: 131-159. doi:10.1016/ bs.mcb.2015.01.018

so Choi HMT, Schwarzkopf M, Fornace ME, Acharya A, Artavanis G, Stegmaier J, Cunha A, Pierce NA. 2018. Third-generation hybridization chain reaction: multiplexed, quantitative, sensitive, versatile, robust. Development 145: dev165753. doi:10.1242/dev.165753

Harland RM. 1991. Appendix G: in situ hybridization: an improved wholemount method for Xenopus embryos. Methods Cell Biol 36: 685-695. doi:10.1016/s0091-679x(08)60307-6

Lee C, Kieserman E, Gray RS, Park TJ, Wallingford J. 2008. Whole-mount fluorescence immunocytochemistry on Xenopus embryos. Cold Spring Harb Protoc doi:10.1101/pdb.prot4957
Sive HL, Grainger RM, Harland RM. 2000. Early development of Xenopus laevis: a laboratory manual. Cold Spring Harbor Laboratory Press, Cold Spring Harbor, New York.

Sive HL, Grainger RM, Harland RM. 2007a. Synthesis and purification of digoxigenin-labeled RNA probes for in situ hybridization. Cold Spring Harb Protoc doi:10.1101/pdb.prot4778

Sive HL, Grainger RM, Harland RM. 2007b. Baskets for in situ hybridization and immunohistochemistry. Cold Spring Harb Protoc doi:10.1101/pdb .prot 4777

Truchado-Garcia M, Harland RM, Abrams MJ. 3D-printable tools for developmental biology: improving embryo injection and screening techniques through 3D-printing technology. biorxiv doi:10.1101/376657 


\section{Whole-Mount RNA In Situ Hybridization and Immunofluorescence of Xenopus Embryos and Tadpoles}

Helen Rankin Willsey

Cold Spring Harb Protoc; doi: 10.1101/pdb.prot105635 originally published online April 7, 2021

\begin{tabular}{|c|c|}
\hline $\begin{array}{r}\text { Email Alerting } \\
\text { Service }\end{array}$ & Receive free email alerts when new articles cite this article - click here. \\
\hline $\begin{array}{l}\text { Subject } \\
\text { Categories }\end{array}$ & $\begin{array}{l}\text { Browse articles on similar topics from Cold Spring Harbor Protocols. } \\
\text { Analysis of Gene Expression (197 articles) } \\
\text { Antibodies (119 articles) } \\
\text { Imaging Development ( } 255 \text { articles) } \\
\text { Imaging/Microscopy, general (579 articles) } \\
\text { Immunodetection ( } 34 \text { articles) } \\
\text { In Situ Hybridization (93 articles) } \\
\text { Labeling for Imaging ( } 339 \text { articles) } \\
\text { Xenopus ( } 210 \text { articles) }\end{array}$ \\
\hline
\end{tabular}

